\title{
The Proposed Conceptual Framework to Understand the Effect of the Technology Organization Environment (TOE) Model on Internet Financial Reporting (IFR) in Libyan Financial Institutions
}

\author{
Saad Lihniash1* ${ }^{*}$, Ibrahim Egdair ${ }^{2}$, Sohail Ahmed ${ }^{3}$ \\ ${ }^{1}$ Deparment of Accounting and Finance, Management and Science University, Shah Alam, Malaysia \\ ${ }^{2}$ School of Technology Management \& Logistics (STML), University Utara Malaysia, Sintok, Malaysia \\ ${ }^{3}$ Faculty of Business Management, University Technology MARA, Shah Alam, Malaysia \\ Email: *saadbubadamare12@gmail.com
}

How to cite this paper: Lihniash, S., Egdair, I. and Ahmed, S. (2019) The Proposed Conceptual Framework to Understand the Effect of the Technology Organization Environment (TOE) Model on Internet Financial Reporting (IFR) in Libyan Financial Institutions. Open Journal of Business and Management, 7, 339-347.

https://doi.org/10.4236/ojbm.2019.72023

Received: January 2, 2019

Accepted: January 30, 2019

Published: February 2, 2019

Copyright $\odot 2019$ by author(s) and Scientific Research Publishing Inc. This work is licensed under the Creative Commons Attribution International License (CC BY 4.0).

http://creativecommons.org/licenses/by/4.0/

\begin{abstract}
The current paper aims to explore a set of internet financial reporting (IFR) among the technology-organization-environment (TOE) model, by the financial institutions in the Libya context. The conceptual framework, and the corporate governance factor and other relationships proposed in the review process to explore the confirmation of the impact of the proposed framework. The discussion with reference to particular financial institutions has some common characteristics that unite their assessment in terms of the government sector. There are many relationships between the three factors technological, organizational, and environmental factors considered. It is important to combine these factors to define their significance in a complete future study. The existing paper suggests a practical framework for the study of the most significant factors, influencing the potential relationship between TOE model and IFR adoption in a clear signal that it has not been studied before in the Libyan context, directly giving the clear signs of such future study, especially in the context of Libya.
\end{abstract}

\section{Keywords}

Technology Organization Environment (TOE) Model, Internet Financial Reporting (IFR), Financial Institutions, Libya

\section{Introduction}

The Technology Organisation Environment (TOE) framework, has been studied 
in several previous experimental studies, which examined the various information systems, in various disciplines such as electronic business in the financial services industry business, and technology electronic and online for small businesses and medium [1]. Recently, in the adoption of IFR operations [2], purchase eBook [3], and green information technology [4], and with ERP adoption system [5], the information technology witnessed significant changes especially by the end of the twentieth century [6]. However, the use of the internet for financial reporting is considered a new phenomenon but rapidly growing [7]. However, an unexpected financial scandal in a country can affect others. After the global financial scandals and the financial crisis in 2008, companies began to pay more attention to improving their ability [8]. Therefore, the demand has increased for the acquisition of the technology in a timelier and transparent financial reporting, and use technology successfully for various forms of business communication and financial reporting [9].

The technology makes the border between all countries disappear [10]. Internet technology has revolutionized the growing number of companies to disclose their financial activities by using website [11]. Based on the company usually exposes the activity via online such as financial reporting, corporate governance, corporate social responsibility (CSR), strategic information, and timeliness, interactivity with the user, navigability and web structure [12]. The Internet is also absorbing, especially with regards to presentation, disclosure and financial reporting [13].

The main objective of the current paper is to explore a conceptual framework regarding the TOE model to adopt IFR in Libya financial institutions reporting, to provide useful information to the financial reporting users, and understanding the TOE model in its conceptual framework indicates that the preparation of financial reports should provide useful information to investors, creditors, and others. In addition, the proposed framework for TOE and IFR is to enhance the meeting the demands of stakeholders to increase the speed and volume of transparent financial information in a timely manner.

\section{Literature Review}

\subsection{Internet Financial Reporting (IFR)}

In the past 30 years, literature has been highlighted in relation to the financial report on the voluntary disclosure of paper-based annual printed reports [14] [15]. Beginning in 1996, the literature was expanded to include studies on the disclosure of financial information via the Internet. It points out that the use of the Internet for the dissemination of corporate information is increasing and that the use of online financial reporting varies from country to country [16]. The Internet has a decisive impact on corporate reporting, Disseminate information on their websites to various stakeholders [17] [18]. As a result of the growing importance of the Internet and its apparent relevance to corporate reporting, it is not surprising that the issue of Internet dissemination has attracted many researchers to discover the potential benefit of the Internet to business re- 
ports [19] [20].

The literature on the level of Libya from the adoption of a rare, generalized and technology, and provide historical and political broad-based information [21] found historical writings in various mass organizations and online resources, and the provision of adoption of relevant technical information in Libya [22]. Internet access officially came to Libya at the end of 1998, but it was not more widely available until early 2000 [23]. In 2005 it launched a national policy on information and communications technology and operated mainly by the Ministry of Education and the Ministry of Vocational Training. In addition, the support of the public telecommunications company mail, Libya Telecom and Technology [24]. The policy in general aims at enabling access to the ICT through the provision of computers and the internet. This is planned for the short term and there are some signs that the policy is being followed up and implemented [23]. The growing acceptance of on a large scale, it is important for organizations to encourage and support innovation and adoption of Internet technologies IS [25]. It IS such as e-commerce technologies. Management Information Systems (MIS), such as accounting information systems, human resources, information systems, and systems projects. Therefore, information systems help in the preparation of important reports in decision-making [26].

On the other hand, Minimarts Marketing group 2011 published the results of Internet usage statistics for Africa which show that $5.7 \%$ of the users in Africa and $5.4 \%$ of the users in Libya were subscribers. In the case of Libya, an Internet subscription is often used by several members of the household, by clients of cybercafés, and by visitors to libraries [23]. In addition, Internet service prices are very high and the service is not all that good. However, it is in the number of Internet users is growing in Libya over the past few years, and will continue to do so [27]. According to Internet World Stats, the number of Internet users in Libya in 2016, i.e. 2.8 million representing $42.8 \%$ of the population.

\subsection{Technology-Organization-Environment (TOE) Model}

Framework technology, organization, environment TOE proposed by [28] for analysis adoption of new innovations in various organizations. The TOE framework is consist of three different main dimensions in influencing the reliance, are the context of technological decisions, organizational context, and environmental context, where technological innovation is the internal and external technology that has organization [29] [30] [31]. In terms of organizational entrance, the measures concerned the organization, such as the structure and framework of the resources, and the size of the organization and the scope of administrative work describes [32]. In terms of the environment represent competition organizations and the industry and how to deal with the government [33].

The technological context focuses on how technologies can affect adoption [28] and relate to operationalization, potential benefits and current regulatory adoption [34]. Typically, the adopter assesses the characteristics of the technology in terms of potential gains and barriers [35] [36]. The expected benefits for 
the Organization to receive at adoption are increased efficiency, quality, and reliability. In addition, comparative advantage suggests that the benefits of online disclosure should exceed the cost of adoption. On the other hand, obstacles point to problems that organizations expect to encounter during the adoption process, such as their complexity and compatibility with the efficiency of organizational and heritage technology systems [37] [38]. In addition, adoption costs, including implementation, maintenance, training, and transition costs, can be seen as barriers to the adoption of technology [39]. According to, [40] recommend that it should complete the look with the adoption of IFR technologies and some factors have not been studied, also to confirm modify TOE model. The current study intends to examine which of these factors is more suitable to influence the adoption of IFR technologies. According to, [41] they proposed that future research may resolve those inconsistencies by incorporating in the theory what the differences between organizations that mostly generate innovations and those that mostly adopt innovations [42].

\section{Methodology}

The methodology of this paper is based on proposed causal research design, to explore the expected framework which was directed in the previous literature, and provide strong understanding in next future practical study, to identify whether any effect of the TOE model factors on the IFR adoption in Libyan financial institutions. The current study proposed to explore the TOE model with the main three factors technological, organizational, and environmental aspect.

The proposed model is a part of a conceptual easier method to inspect some questions and build a hypothesis to support the idea of current paper and consider it using TOE theory, and other possible theories:

1) To what extent the effect of TOE model on the IFR adoption in Libyan financial institutions?

2) Is there any other factors can add value to the original TOE model?

To answer these questions, a theoretical model has been developed based on the TOE model. Figure 1 depicts this model.

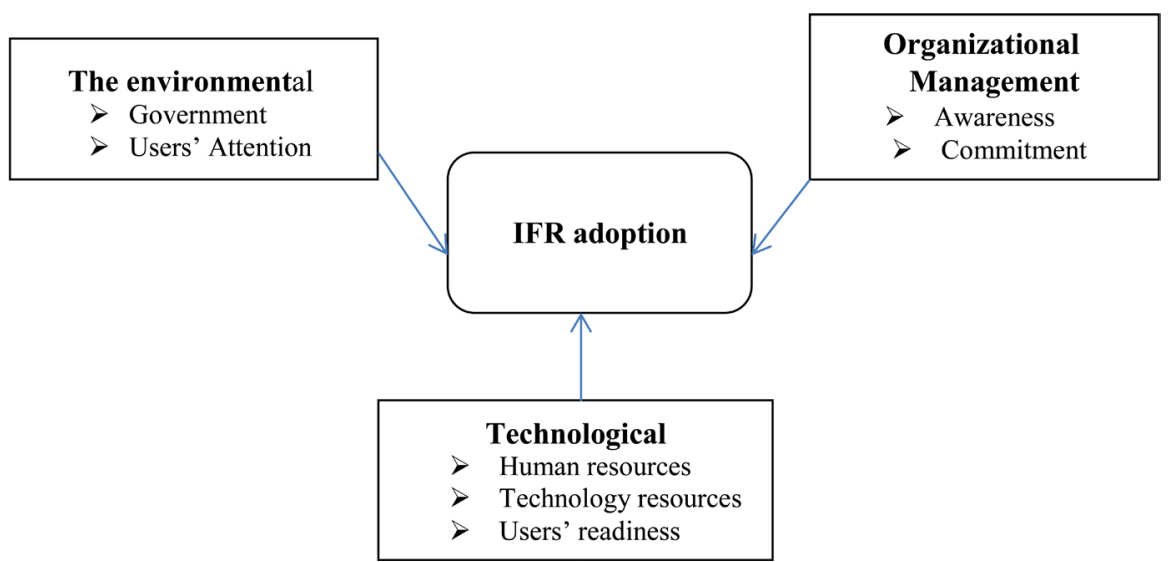

Figure 1. The TOE model of IFR adoption. 


\section{Discussion}

Information technology (IT) has created significant benefits for accounting departments. IT networks and computer systems have shortened the lead time needed by accountants to prepare and present financial information to management and stakeholders. Not only has IT shortened the lead time required to present financial information, but it also has improved the overall efficiency and accuracy of the information [43]. The biggest impact IT has made on accounting is the ability of companies to develop and use computerized systems to track and record financial transactions. Paper ledgers, manual spreadsheets and hand-written financial statements have all been translated into computer systems that can quickly present individual transactions into financial reports [44].

Most of the popular accounting systems can also be tailored to specific industries or companies. This allows companies to create individual reports quickly and easily for management decision making. Additionally, changes can be made relatively easy to reflect any economic changes in business operations [45]. Computerized accounting systems have also improved the functionality of accounting departments by increasing the timeliness of accounting information. By improving the timeliness of financial information, accountants can prepare reports and operations analyses that give management an accurate picture of current operations. The number of financial reports has also been improved by computerized systems; cash flow statements, departmental profit and loss, and market share reports are now more accessible with computerized systems [46].

Most computerized accounting systems have internal check and balance measures to ensure that all transactions and accounts are properly balanced before financial statements are prepared. Computerized systems will also not allow journal entries to be out of balance when posting, ensuring that individual transactions are properly recorded [47].

Accuracy is also improved by limiting the number of accountants that have access to financial information. Less access by accountants ensures that financial information is adjusted only by qualified supervisors [43].

Computerized accounting systems allow accountants to process large amounts of financial information and process it quickly through the accounting system. Quicker processing times for individual transactions has also lessened the amount of time needed to close out each accounting period. Month- or year-end closing periods can be especially taxing on accounting departments, resulting in longer hours and higher labor expense. Shortening this time period aids companies in cost control, which increases overall company efficiency [48]. Reports issued to outside investors and stakeholders have been improved by computerized accounting systems. Improved reporting allows investors to determine if a company is a good investment for growth opportunities and has the potential to be a high-value company. Companies can utilize these investors for equity financing, which they use for expanding business operations [44]. 


\section{Conclusions}

Despite the possibility to exploit the TOE model in Libyan organizations to IFR adoption, there are some other factors can add value to that model such as corporate governance in the organization factor in the TOE model can be used in order to investigate that effect on the IFR in Libyan financial institutions performance. But the success of the efficiency and effectiveness requires good administration and high corporate governance and infrastructure that contribute to supporting the success of new applications. These change strategies according to what fits the success of the projects and survival in the event of what supporting the continuity of these organizations in providing better services and performance. It was noticed that most organizations fail in the field of technological change, mainly because of the inability to control the important factors and opportunities. This paper explores the above conceptual framework, and aimed by answering some important questions that presented the TOE model with the proposed factor may add value to that model most important factors associated with technology and its relationship to the IFR in Libyan financial institutions was a case as one of the countries seeking to achieve the high-performance levels in various areas of the organizations.

The current paper dealt with quick glances of brief understanding of internet financial reporting (IFR) with the proposed understanding TOE model which has different nature in the environmental context in different financial institutions in Libya context. The importance of knowing corporate governance factor to add proposed value to the TOE model on the IFR, that is one of the important issues for the success of the IFR process, it is seeming to be new direction need more investigate, this requires an awareness of this phenomenon and further study of the expansion of knowledge in the practice of corporate governance factor.

\section{Conflicts of Interest}

The authors declare no conflicts of interest regarding the publication of this paper.

\section{References}

[1] Zhu, K., Kraemer, K.L. and Dedrick, J. (2004) Information Technology Payoff in e-Business Environments: An International Perspective on Value Creation of e-Business in the Financial Services Industry. Journal of Management Information Systems, 21, 17-54. https://doi.org/10.1080/07421222.2004.11045797

[2] Verriest, A., Gaeremynck, A. and Thornton, D.B. (2013) The Impact of Corporate Governance on IFRS Adoption Choices. European Accounting Review, 22, 39-77. https://doi.org/10.1080/09638180.2011.644699

[3] Teo, T.S., Lin, S. and Lai, K.-H. (2009) Adopters and Non-Adopters of e-Procurement in Singapore: An Empirical Study. Omega, 37, 972-987. https://doi.org/10.1016/j.omega.2008.11.001

[4] Nedbal, D., et al. (2011) Sustainable IS Initialization through Outsourcing: A 
Theory-Based Approach. AMCIS.

[5] Egdair, I.M., Rajemi, M.F. and Nadarajan, S. (2015) Technology Factors, ERP System and Organization Performance in Developing Countries. International Journal of Supply Chain Management, 4.

[6] Mohammed Sarea, A. (2016) Determinations of Internet Financial Reporting: Evidence form Bahrain Bourse. Jordan Journal of Business Administration, 12.

[7] Khan, M.N.A.A. (2016) The Practice of Internet Financial Reporting in Malaysia: Users' Perceptions. Regional Conference on Science, Technology and Social Sciences (RCSTSS 2014). Springer.

[8] Bansal, N. and Sharma, A.K. (2016) Audit Committee, Corporate Governance and Firm Performance: Empirical Evidence from India. International Journal of Economics and Finance, 8, 103. https://doi.org/10.5539/ijef.v8n3p103

[9] Briones, J.P. and Cabrera, D.P. (2016) Internet Financial Reporting: the Case of Philippine Banks. Jurnal Akuntansi dan Auditing, 13, 1-18.

[10] Sanad, Z.R., Al-Sartawi, A. and Musleh, M. (2016) Investigating the Relationship between Corporate Governance and Internet Financial Reporting (IFR): Evidence from Bahrain Bourse. Jordan Journal of Business Administration, 12. https://doi.org/10.12816/0030063

[11] Jones, M.J. and Xiao, J.Z. (2004) Financial Reporting on the Internet by 2010: A Consensus View. Accounting Forum, Elsevier. https://doi.org/10.1016/j.accfor.2004.07.002

[12] Gallego-Alvarez, I., Rodríguez-Domínguez, L. and García-Sánchez, I.-M. (2011) Information Disclosed Online by Spanish Universities: Content and Explanatory Factors. Online Information Review, 35, 360-385. https://doi.org/10.1108/14684521111151423

[13] Arafa, I. (2012) Evaluating the Impact of Institutional Logic on the Corporate Internet Reporting by Egyptian Listed Companies. Aston University.

[14] Oyelere, P., Laswad, F. and Fisher, R. (2003) Determinants of Internet Financial Reporting by New Zealand Companies. Journal of International Financial Management \& Accounting, 14, 26-63. https://doi.org/10.1111/1467-646X.00089

[15] Almilia, L.S. (2009) Determining Factors of Internet Financial Reporting in Indonesia.

[16] Alanezi, F.S. (2009) Factors Influencing Kuwaiti Companies' Internet Financial Reporting. Journal of Economic and Administrative Sciences, 25, 1-23. https://doi.org/10.1108/10264116200900007

[17] Uyar, A. (2011) Determinants of Corporate Reporting on the Internet: An Analysis of Companies Listed on the Istanbul Stock Exchange (ISE). Managerial Auditing Journal, 27, 87-104. https://doi.org/10.1108/02686901211186117

[18] Laswad, F., Fisher, R. and Oyelere, P. (2005) Determinants of Voluntary Internet Financial Reporting by Local Government Authorities. Journal of Accounting and Public Policy, 24, 101-121. https://doi.org/10.1016/j.jaccpubpol.2004.12.006

[19] Lybaert, N. (2002) On-Line Financial Reporting: An Analysis of the Dutch Listed Firms.

[20] Abdelsalam, O.H., Bryant, S.M. and Street, D.L. (2007) An Examination of the Comprehensiveness of Corporate Internet Reporting Provided by London-Listed Companies. Journal of International Accounting Research, 6, 1-33. https://doi.org/10.2308/jiar.2007.6.2.1

[21] Twati, J. and Gammack, J.G. (2006) The Impact of Organisational Culture Innova- 
tion on the Adoption of IS/IT: The Case of Libya. Journal of Enterprise Information Management, 19, 175-191. https://doi.org/10.1108/17410390610645076

[22] Twati, J.M. (2014) The Influence of Societal Culture on the Adoption of Information Systems: The Case of Libya. Communications of the IIMA, 8, 1-12.

[23] Elzawi, A., et al. (2012) Bridging the Digital Divide and Enhancing the Quality of Engineering Research in Libyan Universities.

[24] Rhema, A. and Miliszewska, I. (2011) Reflections on a Trial Implementation of an e-Learning Solution in a Libyan University. Informing Science and Information Technology, 8, 61-76.

[25] Egdair, I., Rajemi, M.F. and Nadarajan, S. (2017) Review Factors of Organizational Structures and Organization Size on the ERP Adoption System in Public Organization-Libya Context. System, 28, 29.

[26] Avgerou, C. (2008) Information Systems in Developing Countries: A Critical Research Review. Journal of Information Technology, 23, 133-146. https://doi.org/10.1057/palgrave.jit.2000136

[27] Eltkhtash, S. (2013) Internet Financial Reporting in Arab MENA Countries: An Institutional Perspective. University of Dundee, Dundee.

[28] Depietro, R., Wiarda, E. and Fleischer, M. (1990) The Context for Change: Organization, Technology and Environment. The Processes of Technological Innovation, 151-175.

[29] Low, C., Chen, Y. and Wu, M. (2011) Understanding the Determinants of Cloud Computing Adoption. Industrial Management \& Data Systems, 111, 1006-1023. https://doi.org/10.1108/02635571111161262

[30] Melville, N. and Ramirez, R. (2008) Information Technology Innovation Diffusion: An Information Requirements Paradigm. Information Systems Journal, 18, 247-273. https://doi.org/10.1111/j.1365-2575.2007.00260.x

[31] Baker, J. (2012) The Technology-Organization-Environment Framework. In: Information Systems Theory, Springer, Berlin, 231-245.

[32] Jia, Q., Guo, Y. and Barnes, S.J. (2017) Enterprise 2.0 Post-Adoption: Extending the Information System Continuance Model Based on the Technology-OrganizationEnvironment Framework. Computers in Human Behavior, 67, 95-105. https://doi.org/10.1016/j.chb.2016.10.022

[33] Fu, H.-P. and Su, H.-T. (2014) A Framework for a Technology-Organization-Environment Implementation Model in Taiwan's Traditional Retail Supermarkets. The International Journal of Organizational Innovation, 6, 121-129.

[34] Sin Tan, K., et al. (2010) Internet-Based ICT Adoption among SMEs: Demographic versus Benefits, Barriers, and Adoption Intention. Journal of Enterprise Information Management, 23, 27-55.

[35] Ramdani, B., Chevers, D. and Williams, D.A. (2013) SMEs' Adoption of Enterprise Applications: A Technology-Organisation-Environment Model. Journal of Small Business and Enterprise Development, 20, 735-753. https://doi.org/10.1108/JSBED-12-2011-0035

[36] Chau, P.Y. and Tam, K.Y. (1997) Factors Affecting the Adoption of Open Systems: An Exploratory Study. Mis Quarterly, 21, 1-24.

[37] Sahin, I. (2006) Detailed Review of Rogers' Diffusion of Innovations Theory and Educational Technology-Related Studies Based on Rogers' Theory. Turkish Online Journal of Educational Technology, 5, 14-23.

[38] David, J. (2016) The Non-Adoption of XBRL by Professional and Government Or- 
ganisations in New Zealand and Its Implications for Stakeholders.

[39] Troshani, I., Jerram, C. and Rao Hill, S. (2011) Exploring the Public Sector Adoption of HRIS. Industrial Management \& Data Systems, 111, 470-488. https://doi.org/10.1108/02635571111118314

[40] Miniaoui, H. and Oyelere, P. (2013) Determinants of Internet Financial Reporting Practices: Evidence from the UAE. Review of Pacific Basin Financial Markets and Policies, 16, 1350026.

[41] Gopalakrishnan, S., Wischnevsky, J.D. and Damanpour, F. (2003) A Multilevel Analysis of Factors Influencing the Adoption of Internet Banking. IEEE Transactions on Engineering Management, 50, 413-426. https://doi.org/10.1109/TEM.2003.819648

[42] Lippert, S.K. and Govindarajulu, C. (2015) Technological, Organizational, and Environmental Antecedents to Web Services Adoption. Communications of the IIMA, $6,14$.

[43] Ghasemi, M., et al. (2011) The Impact of Information Technology (IT) on Modern Accounting Systems. Procedia Social and Behavioral Sciences, 28, 112-116. https://doi.org/10.1016/j.sbspro.2011.11.023

[44] Hla, D. and Teru, S.P. (2015) Efficiency of Accounting Information System and Performance Measures. International Journal of Multidisciplinary and Current Research, 3, 976-984.

[45] Kerzner, H. and Kerzner, H.R. (2017) Project Management: A Systems Approach to Planning, Scheduling, and Controlling. John Wiley \& Sons, Hoboken.

[46] Gelinas, U.J., Dull, R.B. and Wheeler, P. (2011) Accounting Information Systems. Cengage Learning, Boston.

[47] Yeboah, E., Owusu Kwateng, K. and Oppong, C. (2014) Information Systems and Accounting Practices in Ghanaian Public Institutions.

[48] Aniefor, S.J. (2017) Influence of Information Communication Technology on the Role of Accountants in Nigeria. 